INTERNATIONAL JOURNAL OF RESEARCHES IN BIOSCIENCES, AGRICULTURE AND TECHNOLOGY

(C) VISHWASHANTI MULTIPURPOSE SOCIETY (Global Peace Multipurpose Society) R. No. MH-659/13(N)

www.vmsindia.org

\title{
ROLE OF MEDICINAL LEECHES IN ACHENE VELGARIS
}

\author{
S. S. Deshmukh \\ Shivaji Science College, Congress Nagar Nagpur \\ drshitaldeshmukh@gmail.com
}

\section{Abstract:}

The study was carried out on the patients suffering from Mukhdushika (acne vulgaris) patients were selected from IPD and OPD of the post-graduate department of Shalyatantra of Vidarbha Ayurved Mahavidyalaya and Shree Gopal Nanji Tank Ayurvedic Hospital, Amravati for pilot study only to find out the role of leech Application in the management of Mukhdushika (Acne vulgaris). During treatment it has been found that $85 \%$ patients were taking treatment regularly while $15 \%$ patients were irregular about their treatment. Severity of signs and symptoms Mukhdushika before and after treatment.

Keywords: Leech, patients, Makhdushika, treatment, diet

\section{Introduction:}

The medicinal leech is one of the few parasitic invertebrates widely used in medicine and as a scientific model object. Ayurveda the great medical science of India is now practiced meagerly; but when the challenges of resistant cases are alarming day by day ayurveda is the only hope. No doubt each country has its own traditional medical system, which they practiced since centuries back but due to lack of a well written script it gradually disappears. In India traditional medical system is enriched with a well defined doshik (morbid) theory of disease etiology, types, clinical features, treatment modalities etc. in a very well organized and systematic way, and known as ayurveda. Charka samhita, susrutasamhita, ashtanga sangraha and ashangahridaya are the base books while madhavnidana, sharangdhara samhita, bhavaprakasha etc. are the supplementary books; because of these written textual books ayurveda is still practicing in India with great success. The main drawback of ayurveda is lack of proper literary and medicinal research as well as documentation of prior knowledge. Raktamokshana or bloodletting is practiced in India since thousands of years. Our saints included this procedure under the five bio-purificatory procedures; they said that removal of impure blood from the body treats the root cause of the sufferings.

Medicinal leech, Hirudo medicinalis, has been used in plastic and reconstructive surgery, to relieve venous congestion and to improve the micro revascularization of flaps. (Whitaker etal2012; Fordel et al, 2004) Leech therapy has established itself as an alternative remedy for the treatment of vascular disorders, since leech saliva can temporarily improve blood flow and ameliorate connective tissue hyperalgesia. (Michalsen et al, 2007)Clinical studies revealed that it can reduce blood hypercoagulability with an anti-inflammatory effect in patients with thrombophlebitis. In many countries, wild leeches are still provided from local markets and utilised with antibiotic prophylaxies. In this research, a result of identification of bacteria in the transport fluid is reported, oral and intestinal floras and the antibiograms of the identified microorganisms are investigated. Also, to avoid possible infections, the ability of hypochloric acid, a disinfectant, to suppress the relevant microorganisms without changing the life style and behavior of leeches in terms of sucking function, is investigated. (Baskova et al, 2008) Many therapists used leeches for the healing of hypertension, varicose veins, hemorrhoids, gonarthritis, and secondary ischemia-related dermatosis.( Srivastava et al 2010). After reaching a popular peak in the early nineteenth century, leech trading became a lucrative business which encouraged more people to collect large numbers of leeches, which eventually caused them to become endangered species. Consequently, European and American authorities offered rewards for the invention of a new method to breed leeches Whitakar et al 2004. Meanwhile, leeches were employed to treat mental disorders, skin diseases, gout, headache, and whooping cough Britanica 2012.

\section{Material and Methods:}

The study was carried out on the patients suffering from Mukhdushika (acne vulgaris) patients were selected from IPD and OPD of the post-graduate department of Shalyatantra of Vidarbha Ayurved Mahavidyalaya and Shree Gopal Nanji Tank Ayurvedic Hospital, Amravati for pilot study only to find out the role of leech Application in the management of Mukhdushika (Acne vulgaris).

The aims and objectives of the study were 
1) To find out the efficacy of Jaloukavacharan (Leech application) in the management of Mukhdushika (Acne vulgaris)

2) To find out safe, simple and effective remedy i.e. Leech application for Mukhdushika (Acne vulgaris).

The selected patients were divided into following four different groups consisting of minimum 20 patients.

1) First group was treated by Leech Application.

2) Second Group was treated by Leech Application along with local application of Lodharadhi Lepa and Sarivadikwatha orally.

3) Third Group was treated with Leech Application along with antibiotics.

4) Fourth Group was treated with modern medicinal of treatment like Antibiotics.

\section{Investigations:}

The common investigations performed were

Blood for-

1.Haemoglobin estimation

2.Total leucocyte count

3.Differential Leucocyte count

4.Bleeding time

Clotting time

Erythrocyte Sedimentation Rate

Blood Sugar-fasting Post prandial.

The surgical bio-instrument i.e. Leeches were made available and preserved under the standard lines as mentioned in the classical tests. The method of application of leeches is according to ancient method as described by Acharya Sushrut.

The Process of Leech application was carried out in the phased manner in Pre-operative, operative and post-operative management.

1) Pre-Operative (Purvakarma)

In pre-operative process leeches were kept in haridrakalka (past of turmeric) and water for a minute. Then leeches were kept in fresh water for two minutes. These leeches were used for application. Leech application was done to the selected patients in sitting position.

2) Operative ( Pradhankarma)

In operative procedure leeches were applied. The number of leeches varied according to the size of affected area. In $5 \mathrm{~cm}$ area one leech was applied.

The affected area was cleaned with water. Then leech was applied. For easy attachment of leech minor puncture was done by a sterile needle. Then also if the leech doesn't get attached another leech was applied.

3) Post-Operative (Paschyat Karma)

In post operative process leeches are removed from the site by sprinkling turmeric powder.
Generally leeches leaves the site on its own, when it gets completely filled with blood.

Blood from the gut of the leeches are removed by slowly and gently squeezing them from tail to mouth. Then dressing is done by turmeric powder and tight bandage is applied.

The leech application was done once a week and single leech was applied for each patient. As it is a OPD procedure so patients need not to admit in the hospital.

For the second group along with leech application sarivadikwatha $(20 \mathrm{ml})$ was given orally and Lodhradilepa was given for local application.

In the Third group along with leech application antibiotic erythromycin $250 \mathrm{mg}$ QID was given for local application.

In the Fourth group patients were treated by modern medicinal line of treatment. They were given erythromycin $250 \mathrm{mg}$ QID along with local application of Benzoyl peroxide 5\% ointment.

All the patients were advised regarding facial hygiene which includes.

i) Washing the face with medicated soap, thrice a day.

ii) Not rubbing the face while washing.

iii) Keeping the face dry/oil free.

iv) Avoidance of acneigenic drugs and agents like oils, brilliantines or heavy cosmetics.

v) Elimination of emotional stress.

The complete record along with the history of the patient, all necessary investigations and the progress was noted down in the standard proforma which was prepared in the department under the guidance of head of the department.

\section{Observations and Discussion:}

Table 1.- Group-wise distribution of patients.

\begin{tabular}{|c|c|c|c|}
\hline Sr. No. & Group & No. of Patients & Percentage \\
\hline 1 & I & 20 & $25 \%$ \\
\hline 2 & II & 20 & $25 \%$ \\
\hline 3 & III & 20 & $25 \%$ \\
\hline 4 & IV & 20 & $25 \%$ \\
\hline Total & & 80 & $100 \%$ \\
\hline
\end{tabular}

Table 2.- Sex -wise distribution of patients

\begin{tabular}{|c|c|c|c|}
\hline Sr. No. & Sex & No. of Patients & Percentage \\
\hline 1 & Male & 46 & $57.50 \%$ \\
\hline 2 & Female & 34 & $42.25 \%$ \\
\hline Total & & 80 & $100 \%$ \\
\hline
\end{tabular}

Table 3.- Diet-wise distribution of patients

\begin{tabular}{|l|l|l|l|}
\hline Sr.No. & Diet & $\begin{array}{l}\text { No. of } \\
\text { Patients }\end{array}$ & $\begin{array}{l}\text { Percenta } \\
\text { ge }\end{array}$ \\
\hline 1 & vegetarian & 16 & $20 \%$ \\
\hline 2 & $\begin{array}{l}\text { Non- } \\
\text { vegetarian }\end{array}$ & 22 & $27.25 \%$ \\
\hline 3 & Mixed & 42 & $52.50 \%$ \\
\hline Total & & 80 & $100 \%$ \\
\hline
\end{tabular}


In Present study, out of 80 patients 46 patients were male and 34 patients were female. Out of 80 patients, $52.50 \%$ patients were taking mixed diet,27.25 patients were Non-vegetarian and $20 \%$ patients were vegetarian.

Table 3.- Area-wise distribution of patients

\begin{tabular}{|l|l|l|l|}
\hline Sr.No. & Sex & No. of Patients & Percentage \\
\hline 1 & Rural & 24 & $30 \%$ \\
\hline 2 & Urban & 56 & $70 \%$ \\
\hline Total & & 80 & $100 \%$ \\
\hline
\end{tabular}

Above table shows that 56 patients out of 80 patients were from rural area while 26 patients were from urban area.

Table 3.- Class wise distribution of patients

\begin{tabular}{|l|l|l|l|}
\hline Sr.No. & Status & $\begin{array}{l}\text { No. of } \\
\text { Patients }\end{array}$ & Percentage \\
\hline 1 & $\begin{array}{l}\text { Higher } \\
\text { Class }\end{array}$ & 15 & $18.75 \%$ \\
\hline 2 & $\begin{array}{l}\text { Middle } \\
\text { Class }\end{array}$ & 53 & $66.25 \%$ \\
\hline 3 & Poor Class & 12 & $15 \%$ \\
\hline Total & & 80 & $100 \%$ \\
\hline
\end{tabular}

The above table shows that maximum number of patients i.e 53 patients belong to higher class.

Table 3. Occupation wise distribution of patients

\begin{tabular}{|l|l|l|l|}
\hline Sr.No. & Occupation & $\begin{array}{l}\text { No. of } \\
\text { Patients }\end{array}$ & Percentage \\
\hline 1 & Students & 43 & $53.75 \%$ \\
\hline 2 & Service & 10 & $12.50 \%$ \\
\hline 3 & Businessman & 07 & $8.75 \%$ \\
\hline 4 & Househould & 15 & $18.75 \%$ \\
\hline 5 & others & 5 & $6.25 \%$ \\
\hline Total & & 80 & $100 \%$ \\
\hline
\end{tabular}

The Above table shows that out of 80 patients maximum $53.75 \%$ i.e. 43 patients were students.

Table 3.- Chronicity (Duration) wise distribution of patients

\begin{tabular}{|l|l|l|l|}
\hline Sr.No. & $\begin{array}{l}\text { Chronicity } \\
\text { (Duration) }\end{array}$ & $\begin{array}{l}\text { No. of } \\
\text { Patients }\end{array}$ & Percentage \\
\hline 1 & Upto 1 year & 55 & $68.75 \%$ \\
\hline 2 & Upto 2 year & 15 & $18.75 \%$ \\
\hline 3 & Above 2 year & 10 & $12.50 \%$ \\
\hline Total & & 80 & $100 \%$ \\
\hline
\end{tabular}

In our study, Maximum numbers of patients were having 1 year duration i.e 55 patients and 15 patients were having 2 years duration while remaining 10 patients were having duration above 2 years.

Table 3.- Distribution according to recurrent and fresh nature.

\begin{tabular}{|l|l|l|l|}
\hline Sr.No. & Nature & $\begin{array}{l}\text { No. of } \\
\text { Patients }\end{array}$ & Percentage \\
\hline 1 & Fresh & 56 & $70 \%$ \\
\hline 2 & Reccurrent & 24 & $30 \%$ \\
\hline Total & & 80 & $100 \%$ \\
\hline
\end{tabular}

Present study of 80 patients contains 56 fresh patients and 24 recurrent patients.

Table 3.- Regularity in attending Hospital

\begin{tabular}{|l|l|l|l|}
\hline Sr.No. & Regularity & $\begin{array}{l}\text { No.of } \\
\text { Patients }\end{array}$ & Percentage \\
\hline 1. & Regular & 68 & $85 \%$ \\
\hline 2. & Irregular & 12 & $15 \%$ \\
\hline Total & & 80 & $100 \%$ \\
\hline
\end{tabular}

\section{Conclusion:}

During treatment it has been found that $85 \%$ patients were taking treatment regularly while $15 \%$ patients were irregular about their treatment.

Severity of signs and symptoms Mukhdushika before and after treatment.

1) Pain:- In Group I,out of 14 patients, two patients got relief after 24 hours. All the 14 patients got relief after 3 weeks.

In Group II, out of 12 patients, four patients got relief after 24 hours and it took 2 weeks for all patients to get relief from pain.

In Group III, out of 13 patients four patients got relief after 24 hours and all 13 patients got relief after 3 weeks.

In Group IV, out of 12 patients, four patients got relief after one week and it took 4 weeks for all 12 patients to get relief from pain.

2) Redness:-Mild redness was reduced completely in group I,group II and group III after 2 weeks while moderate redness was reduced after 3 weeks in group I,group II and group III whereas in group IV mild redness was reduced in 4 weeks and moderate redness was reduced in 5 weeks.

3) Tenderness:- In Group I, out of 12 patients of mild tenderness two patients got relief after 24 hours and all patients of mild tenderness got relief in 2 weeks, while moderate tenderness was relieved in 4 weeks.

In Group II, out of 10 patients of mild tenderness two patients got relief after relief after 24 hours and all patients got of mild tenderness got relief in 2 weeks, while moderate tenderness was relieved after 3 weeks.

In Group III, out of 12 patients of mild tenderness three patients got relief after 24 hours while it took 3 weeks for complete relief. Moderate tenderness was relived after 4 weeks.

In Group IV, mild tenderness was relieved after 4 weeks while moderate tenderness was relived after 5 weeks.

4) Scarring:- In Group I, out of 8 patients of mild scarring five patients were improved after 10 weeks while in $2^{\text {nd }}$ degree scarring out of 8 patients two patients were improved after 10 weeks and in case of $3^{\text {rd }}$ degree scarring out of 4 patients was improved after 10 weeks. 
In Group II, in case of 10 patients of mild scarring 7 patients were improved and in case of severe scarring out of 3 patients one patient was improved after 10 weeks. In Group III, out of 7 patients of mild scarring 3 patients were improved, while in case of moderate scarring out of 9 patients 2 patients were improved and in case of severe scarring out of 4 patients one patient was improved after 10 weeks.

In Group IV, out of 9 patients of mild scarring 2 patients were improved, while out of 5 patients of moderate scarring 1 patient was improved and out 5 patients of moderate scarring 1 patient was improved and out of 5 patients of severe scarring one patient was improved after 10 weeks.

\section{References:}

1. A. Michalsen, M. Roth, and G. Dobos, Medicinal Leech Therapy, Georg Thieme, New York, NY, USA, 2007.

2. Baskova IP, Kostrjukova ES, Vlasova MA, Kharitonova OV, Levitskiy SA, Zavalova LL, et al. Proteins and peptides of the salivary gland secretion of medicinal leeches Hirudoverbana, $H$. medicinalis, and H. orientalis. Biochemistry (Mosc) 2008;73:315-20.

3, Britanica. Leech: Encyclopedia Britanica. 2012. [Cited on 2012 Mar 31].

4. I. S. Whitaker, O. Oboumarzouk, W. M. Rozen et al., "The efficacy of medicinal leeches in plastic and reconstructive surgery: a systematic review of 277 reported clinical cases," Microsurgery, vol. 32, no. 3, pp. 240-250, 2012.

5. J. L. Frodel Jr., P. Barth, and J. Wagner, "Salvage of partial facial soft tissue avulsions with medicinal leeches," Otolaryngology, vol. 131, no. 6, pp. 934-939, 2004.

6. Michalsen A, Roth M, Dobos G, Aurich M. Stattgurt, Germany: Apple Wemding; 2007. Medicinal Leech Therapy.

7. Whitaker IS, Rao J, Izadi D, Butler PE. Historical article: Hirudomedicinalis: Ancient origins of, and trends in the use of medicinal leeches throughout history. Br J Oral Maxillofac Surg. 2004;42:133-7.

8. Srivastava A, Sharma R. A brief review on applications of leech therapy. Arch ApplSci Res. 2010;2:271-4. 